\title{
Analysis of 16S rRNA Gene Sequences of Vibrio costicola Strains: Description of Salinivibrio costicola gen. nov., comb. nov.
}

\author{
E. MELLADO, ${ }^{1,2}$ E. R. B. MOORE ${ }^{2}$ J. J. NIETO,${ }^{1}$ AND A. VENTOSA ${ }^{1 *}$ \\ Department of Microbiology and Parasitology, Faculty of Pharmacy, University of Seville, Seville, Spain, ${ }^{1}$ and \\ Department of Microbiology, GBF-National Research Centre for Biotechnology, Braunschweig, Germany ${ }^{2}$
}

\begin{abstract}
The phylogenetic positions of six Vibrio costicola strains were determined by direct sequencing and analysis of their PCR-amplified 16S ribosomal DNAs. A comparative analysis of the sequence data revealed that the moderate halophile $V$. costicola forms a monophyletic branch that is distinct from other Vibrio species and from moderately halophilic species of other genera. These results complement phenotypic and genotypic data determined previously. The molecular evidence, together with several phenotypic differences, distinguishes $V$. costicola from species of the genus Vibrio and other species belonging to the gamma subclass of the Proteobac$t$ teria and indicates that $V$. costicola should be placed in a new and separate genus. The name Salinivibrio costicola gen. nov., comb. nov. is proposed for this bacterium. The guanine-plus-cytosine content of the DNA is 49.4 to $50.5 \mathrm{~mol} \%$. The type strain of $S$. costicola is strain NCIMB 701 (= ATCC 33508).
\end{abstract}

Vibrio costicola is a moderately halophilic bacterium that was originally isolated from salted foods (29) and grows optimally in media containing $10 \%$ (wt/vol) salts (7). This species has been isolated frequently from salted meats and brines $(8,28)$, and it has been determined only recently that $V$. costicola is a normal inhabitant of hypersaline environments $(7,19,32)$. In fact, $V$. costicola is the predominant organism in saltern pond waters that have intermediate salt concentrations (concentrations between 10 and $15 \%$ ) (26). $V$. costicola has been also isolated from other saline habitats, such as saline soils, but in lower proportions (24). Until recently, only a few moderately halophilic species had been described, and $V$. costicola was widely used by researchers as a model for the study of the physiological features of obligate halophiles. Thus, in many respects, $V$. costicola has been considered the representative model for studies of moderately halophilic bacteria and has been used as the moderately halophilic organism in which osmoregulatory and other physiological mechanisms have been studied $(15,16)$.

A recent study of isolates obtained from hypersaline habitats and four strains isolated from cured meats demonstrated that $V$. costicola is widely distributed in hypersaline aquatic environments, and an emended description of this species was proposed by García et al. (7). In addition, DNA-DNA homology studies revealed the genotypic homogeneity of representative strains of this species (11), and this species was shown to be not closely related to other Vibrio species $(3,11)$. The data in these studies suggested that $V$. costicola should be placed in a separate genus (3).

Recently, Kita-Tsukamoto et al. (14) compared partial 16S rRNA sequences (approximately 600 nucleotides) of a large number of Vibrio species, and the resulting data also demonstrated that $V$. costicola is not related to other Vibrio species or related organisms. While the manuscript of this paper was being prepared, Ruimy et al. (27) described the complete $16 \mathrm{~S}$ rRNA and ribosomal DNA (rDNA) sequences of the type strain of $V$. costicola in their comprehensive study of Vibrio, Photobacterium, Aeromonas, and Plesiomonas sequences. The

\footnotetext{
* Corresponding author. Mailing address: Department of Microbiology and Parasitology, Faculty of Pharmacy, University of Seville, 41012 Seville, Spain. Phone: 345455 6765. Fax: 345462 8162. Electronic mail address: Ventosa@cica.es.
}

analysis of these authors also demonstrated that $V$. costicola clusters outside the main body of Vibrio species (that is, Vibrio cholerae and related species). In this study, we determined the nearly complete $16 \mathrm{~S}$ rRNA gene sequences of several $V$. costicola strains, including the type strain, and our results confirm that the phylogenetic distances between this species and the other Vibrio species are relatively large $(14,27)$. On the basis of these data and other data, we formally propose that $V$. costicola should be transferred to a new genus as Salinivibrio costicola gen. nov., comb. nov.

The moderately halophilic strains which we studied were $V$. costicola NCIMB $701^{\mathrm{T}}$ (T = type strain), AV3, E-367, V-15, 6, and $\mathrm{H}-178$. The $V$. costicola type strain and strains 6 and AV3 were originately isolated from cured meat (8), while the other $V$. costicola strains were isolated from salterns located in different areas of Spain (7). Cells were grown in a medium containing $0.5 \%$ (wt/vol) yeast extract (Difco) and a salt mixture (final salt concentration, $10 \%$ ) (32). The $\mathrm{pH}$ was adjusted to 7.5 , and the preparations were incubated at $37^{\circ} \mathrm{C}$ in an orbital shaker at 200 strokes per min. When necessary, the medium was solidified by adding $20 \mathrm{~g}$ of Bacto Agar (Difco) per liter.

Genomic DNA isolation, PCR amplification of the $16 \mathrm{~S}$ rRNA genes, and direct determination of the PCR-amplified $16 \mathrm{~S}$ rDNA sequences were carried out by using methods that have been described previously in detail (20). The sequences which we obtained were aligned with reference 16S rRNA and rRNA gene sequences by using the evolutionarily conserved primary sequence and the secondary structure as references $(10,34)$. Dendrograms were generated from comparisons of pairs of sequences and evolutionary distances (12) by using a pairwise, weighted, least-squares distance method (22). Maximum-likelihood analyses were performed by using fast DNA-ML (18).

The nearly complete primary sequences $(1,502$ to $1,512 \mathrm{nu}$ cleotide positions) of the $16 \mathrm{~S}$ rRNA genes of six $V$. costicola strains (including the type strain) were determined and deposited in the EMBL data library. The PCR allowed us to amplify all of the gene encoding the $16 \mathrm{~S}$ rRNAs of these microorganisms except nucleotide positions at the $5^{\prime}$ and $3^{\prime}$ termini of the gene. After the optimal alignment was determined, the sequences of the six $V$. costicola strains were compared with a database consisting of more than 2,000 prokaryotic sequences (18).

The 16S rDNA sequence comparisons unequivocally showed 


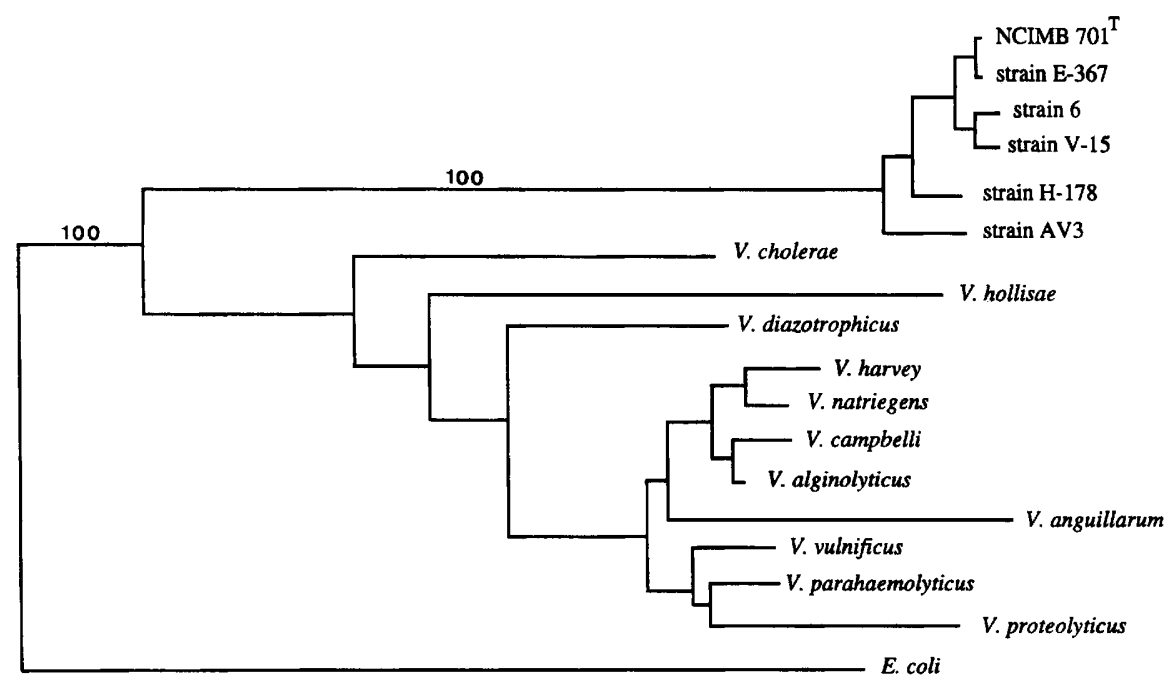

$1 \%$ sequence divergence

FIG. 1. Unrooted phylogenetic tree derived from an analysis of the complete $16 \mathrm{~S}$ rRNA sequences of six $V$. costicola strains (strains NCIMB $701^{\mathrm{T}}$, E-367, 6, V-15, H-178, and AV-3) and other species of the genus Vibrio. The topology was obtained by using an evolutionary distance method. The same topology was obtained when a maximum-likelihood method was used. Bootstrap values (6) that were generated from 100 replications are given for the $V$. costicola branch.

that $V$. costicola clusters in the gamma subclass of the Proteobacteria. Although other moderately halophilic species belonging to the genera Halomonas, Deleya, and Halovibrio are also included in this phylogenetic subdivision, our results indicate that these organisms are not related to $V$. costicola. Dobson et al. (4) pointed out that Halovibrio variabilis is closely related to species of the genera Halomonas and Deleya. Our data support this relationship and establish that the genera Halovibrio, Halomonas, and Deleya, which also include moderate halophiles, constitute a phylogenetic branch that is completely different from the $V$. costicola branch.

The levels of sequence similarity for the six $V$. costicola strains ranged from $98.6 \%$ (level of sequence similarity between strains E-367 and AV3) to $99.9 \%$ (level of sequence similarity between strains NCIMB $701^{\mathrm{T}}$ and E-367). The high levels of similarity of the $V$. costicola strains which we studied at the molecular level, regardless of their origins or sources of isolation, are remarkable.

An unrooted phylogenetic tree derived from the calculated evolutionary distances obtained for $V$. costicola and other species of the genus Vibrio is shown in Fig. 1. The six strains of $V$. costicola are clearly phylogenetically distinct from the other Vibrio species, including $V$. cholerae, the type species of the genus Vibrio; the levels of sequence similarity between the six $V$. costicola strains and $V$. cholerae ranged from 86.8 to $87.1 \%$. Such sequence similarity values are much lower than the similarity values typically observed for species belonging to the same genus. For example, the average level of $16 \mathrm{~S}$ rRNA sequence similarity for the other Vibrio species for which sequence data exist was $95 \%$, and the values ranged from $90 \%$ (level of sequence similarity between $V$. cholerae and Vibrio hollisae) to $99.5 \%$ (level of sequence similarity between Vibrio campbellii and Vibrio alginolyticus). These values demonstrate the heterogeneity of the genus Vibrio as it is currently defined, and the recommendations of Ruimy et al. (27) for reassignment of some Vibrio species to separate genera should be considered. The levels of sequence similarity between $V$. cos- ticola strains and $V$. cholerae (and other species of this genus) are markedly lower than any other sequence similarity values obtained for Vibrio species. It should be pointed out that we determined the 16S rRNA gene sequences of several strains of $V$. costicola, and thus the species is defined phylogenetically not only on the basis of its type strain, but also on the basis of five other strains isolated from very different hypersaline environments or from cured meats.

In addition, it is important to note that the closest genetic relatives of $V$. costicola are not other Vibrio species but the species belonging to the genus Photobacterium. Figure 2 shows the relationships of $V$. costicola to representative species of genera belonging to the gamma subdivision of the Proteobacteria. Gauthier et al. (9) recommended that reassignment of $V$. costicola and $V$. hollisae to the genus Photobacterium should be considered on the basis of the results of $16 \mathrm{~S}$ rRNA gene sequence comparisons and the ability of the organisms to accumulate polyhydroxybutyrate, which is characteristic of the species belonging to the genus Photobacterium. However, the levels of sequence similarity between $V$. costicola NCIMB $701^{\mathrm{T}}$ and Photobacterium species (Photobacterium phosphoreum, 89.5\%; Photobacterium angustum, $89.7 \%$; Photobacterium damsela subsp. piscicida, 91.2\%; Photobacterium leiognathi, 89.3\%) clearly show that $V$. costicola comprises a branch that is evolutionarily distinct from the Photobacterium branch. In addition, the primary sequence of the $16 \mathrm{~S}$ rRNA genes of $V$. costicola has insertions at helices between positions 183 and 193 (Escherichia coli 16S rRNA gene sequence numbering) and positions 207 and 214. These differences in the primary sequence, which produce significant secondary structure changes, are found in the sequences of all strains of $V$. costicola, but are not present in the sequences of any Vibrio or Photobacterium species.

Figure 2 shows the inferred relative phylogenetic relationships of $V$. costicola with other species belonging to the gamma subclass of the Proteobacteria, including other moderately halophilic species. $V$. costicola is quite distinct from the other mod- 




$2 \%$ sequence divergence

FIG. 2. Unrooted phylogenetic tree determined by using masked (17) $16 \mathrm{~S}$ rRNA sequence comparisons of six $V$. costicola strains (strains NCIMB $701^{\mathrm{T}}$, E-367, 6, V-15, H-178, and AV-3), other moderately halophilic species, and other members of the gamma subclass of the Proteobacteria. The topology was obtained by using an evolutionary distance method. The same topology was obtained when a maximum-likelihood method was used. Bootstrap values (6) that were generated from 100 replications are given for the $V$. costicola branch.

erate halophiles $(4,20)$, and these phylogenetic data reflect the phenotypic and chemotaxonomic differences between these species and $V$. costicola (7).

In a previous study that was based on a numerical analysis of phenotypic characteristics of 54 isolates obtained from several salterns, we showed that these strains were very similar to the type strain of $V$. costicola and to three other reference strains originally isolated from cured meats. Thus, an emended description of $V$. costicola was proposed (7). Although $V$. costicola has phenotypic features that are characteristic of species of the genus Vibrio, the phylogenetic relationships of this species with other Vibrio species, as well as with other moderately halophilic gram-negative species, were not known. In this study we estimated the phylogenetic position of $V$. costicola on the basis of the results of a comparison of the nearly complete $16 \mathrm{~S}$ rDNA sequences of six strains of $V$. costicola, including type strain NCIMB 701, two strains isolated from salted foods, and three new isolates obtained from water samples from salterns in geographically distinct areas. Our sequence data clearly demonstrated that these six strains form a homogeneous cluster that is phylogenetically distinct from the species of the genus Vibrio that have been analyzed previously (Fig. 1) and that the calculated evolutionary distance of this cluster from the type species of the genus Vibrio, $V$. cholerae, is clearly large enough to warrant placement of $V$. costicola in a separate genus. Our results expand and confirm the results of a study of marine bacteria, mainly members of the family Vibrionaceae, that was based on determinations of partial $16 \mathrm{~S}$ rRNA sequences (14), in which $V$. costicola was tentatively shown to be distinct from other vibrios. While our data are consistent with the data determined previously, we should point out that the regions sequenced in the previous study were not the regions which we found to be the most informative for the six strains of $V$. costicola when they were compared with other Vibrio species. Ruimy et al. (27) reported that $V$. costicola was most closely related to $V$. hollisae, Vibrio damsela, and species of the genus Photobacterium and was not closely related to $V$. cholerae and the other Vibrio species which they analyzed.
The sequence of the $V$. costicola strain studied by Ruimy et al. (27) (listed as NCIMB $701^{\mathrm{T}}$ ) was compared with the sequence of the same strain determined in this study. Correspondence between workers in the two laboratories was able to explain most of the differences between the sequences (21). However, there are five nucleotides that are different in the two sequences, and the differences may be attributed to the different methods used to determine the sequence. The $16 \mathrm{~S}$ rDNA sequence of $V$. costicola NCIMB $701^{\mathrm{T}}$ determined in this study was used in all of our sequence comparisons and phylogenetic analyses. The only significant differences in the conclusions of the two studies are due to differences in the $16 \mathrm{~S}$ rRNA sequences of $V$. hollisae. The sequence of $V$. hollisae CIP $101886^{\mathrm{T}}$ determined and used by Ruimy et al. (27) differs from the previously published sequence of $V$. hollisae ATCC $33564^{\mathrm{T}}$ (5) by more than $4 \%$ (approximately 60 nucleotide positions). We used the earlier published sequence for the analysis in this study. While it is important to explain the difference observed, our analysis of $V$. costicola was not affected significantly.

It is noteworthy that the limited molecular data previously available for $V$. costicola also suggested that this species was not closely related to other Vibrio species. The level of DNADNA homology of $V$. costicola and $V$. cholerae was found to be as low as $3 \%$ (3) or $2 \%$ (2). In addition, the low levels of DNA relatedness between $V$. costicola and other Vibrio species led previous authors to propose that this species (as well as other Vibrio species) should be placed in a separate genus (3). In a recent study, the levels of DNA-DNA homology between $V$. costicola NCIMB $701^{\mathrm{T}}$ and isolates obtained from hypersaline environments and reference strains obtained from cured meats were determined to be very high $(>70 \%)$, and the authors concluded that these organisms belong to the same genospecies (11). In contrast, the levels of DNA-DNA relatedness with other type strains of Vibrio species were very low, as were the levels of relatedness with other moderately halophilic species, such as Deleya halophila and Halomonas halmophila (11). These DNA-DNA hybridization results are consistent with the 
TABLE 1. Phenotypic characteristics that differentiate the genus Salinivibrio from the genus Vibrio and other related gram-negative genera ${ }^{a}$

\begin{tabular}{|c|c|c|c|c|c|c|c|c|}
\hline Characteristic & Salinivibrio & Vibrio & Halovibrio & Deleya & Halomonas & Chromohalobacter & Volcaniella & Arhodomonas \\
\hline Morphology & Curved rods & Straight or curved rods & Curved rods & Rods & Rods & Rods & Short rods & Short rods \\
\hline Pigmentation & None & Cream & Light brown & None & Cream-yellow & Violet & None & None \\
\hline \multicolumn{9}{|l|}{ Flagellation } \\
\hline Polar & $t^{b}$ & + & + & - & - & - & - & + \\
\hline Peritrichous & - & - & - & $(+)$ & $(+)$ & + & - & - \\
\hline Oxidase activity & + & + & + & $(+)$ & + & - & - & - \\
\hline Growth without $\mathrm{NaCl}$ & - & $(-)$ & - & - & $(-)$ & $(-)$ & - & - \\
\hline $\begin{array}{l}\text { Growth in the presence } \\
\text { of } 20 \% \mathrm{NaCl}\end{array}$ & + & - & + & $(+)$ & + & + & + & + \\
\hline $\begin{array}{l}\text { Optimal growth in the } \\
\text { presence of } 5 \text { to } 10 \% \\
\text { salt }\end{array}$ & + & - & + & + & + & + & + & + \\
\hline Anaerobic growth & + & + & - & - & - & - & - & - \\
\hline $\begin{array}{l}\text { Acid production from } \\
\text { D-glucose }\end{array}$ & + & + & - & + & \pm & + & - & ND \\
\hline \multicolumn{9}{|l|}{ Hydrolysis of: } \\
\hline Gelatin & + & $(+)$ & - & - & ND & - & + & - \\
\hline Starch & - & $(+)$ & - & ND & ND & - & - & - \\
\hline $\begin{array}{l}\text { Voges-Proskauer } \\
\text { reaction }\end{array}$ & + & $(-)$ & ND & ND & ND & - & - & - \\
\hline Indole production & - & ND & - & ND & $(-)$ & - & - & - \\
\hline$\beta$-Galactosidase activity & - & $+1-$ & ND & ND & ND & - & ND & ND \\
\hline \multicolumn{9}{|l|}{ Decarboxylases activities } \\
\hline Arginine & + & - & - & - & ND & - & ND & - \\
\hline Lysine & - & $+1-$ & - & ND & ND & - & ND & - \\
\hline Ornithine & - & $+1-$ & - & ND & ND & - & ND & - \\
\hline $\mathrm{G}+\mathrm{C}$ content $(\mathrm{mol} \%)$ & $49.4-50.5$ & $38-51$ & 61 & $52-68$ & $59-63$ & $62.1-64.9$ & $59.1-65.7$ & 67 \\
\hline
\end{tabular}

${ }^{a}$ Data from references $1,2,7,13,23,25,30,31$, and 33 .

${ }^{b}+$, positive; -, negative; $(+)$, most species are positive; $(-)$, most species are negative; ND, not determined.

data that were obtained in this study and previous studies and were based on 16S rRNA gene sequence comparisons.

Because of the significant phenotypic and genotypic differences between $V$. costicola and other Vibrio species, as well as other bacteria belonging to the gamma subclass of the Proteobacteria, we propose that $V$. costicola should be transferred to a new genus, the genus Salinivibrio, as Salinivibrio costicola gen. nov., comb. nov. Table 1 shows useful features for distinguishing the genus Salinivibrio from the genus Vibrio and other related genera which include moderately halophilic species. More detailed data that can be used to differentiate $S$. costicola from related Vibrio species, as well as moderately halophilic species, have been reported elsewhere recently $(1,7,30)$. A description of the genus Salinivibrio, which is the third genus (along with the genera Vibrio and Photobacterium) in the family Vibrionaceae $(9,27)$, is given below.

Description of the genus Salinivibrio gen. nov. Salinivibrio (Sa.li.ni.vib'ri.o. L. adj. salinus, saline; L.v. vibrio, move rapidly to and from, vibrate; M.L. masc. n. Salinivibrio, saline organism which vibrates). Gram negative. Cells are curved rods that are $0.5 \mu \mathrm{m}$ wide and 1.5 to $3.2 \mu \mathrm{m}$ long and occur singly or occasionally united by $\mathrm{S}$ shapes or spirals. Motile by means of one polar flagellum. Spores are not formed. Colonies are circular, convex, opaque, and cream colored. Broth cultures are uniformly turbid.

Moderately halophilic. Grows in the presence of marine salt concentrations between 0.5 and $20 \%$ (wt/vol) and optimally in the presence of $10 \%(\mathrm{wt} / \mathrm{vol})$ salts at $37^{\circ} \mathrm{C}$. No growth occurs in the absence of $\mathrm{NaCl}$. Growth occurs at 5 to $45^{\circ} \mathrm{C}$ (optimal growth occurs at $37^{\circ} \mathrm{C}$ ) and at $\mathrm{pH} 5$ to 10 (optimal growth occurs at $\mathrm{pH} 7.5$ ).

Facultatively anaerobic. Catalase and oxidase are produced. Chemoheterotrophic. Acid but no gas is produced from Dglucose. Gelatin is hydrolyzed, but starch is not hydrolyzed.
Voges-Proskauer and arginine decarboxylase tests are positive. Indole, $\beta$-galactosidase, lysine decarboxylase, and ornithine decarboxylase tests are negative.

The DNA base composition ranges from 49.4 to $50.5 \mathrm{~mol} \%$ $\mathrm{G}+\mathrm{C}$ (as determined by the thermal denaturation method). Isolated from hypersaline environments (salterns, saline soils) and from salted food (cured meats and brines). The type species is Salinivibrio costicola (formerly Vibrio costicola). The genus Salinivibrio is a member of the gamma subclass of the Proteobacteria.

The description of Salinivibrio costicola comb. nov. is based on the data of García et al. (7). The type strain of this species is strain NCIMB 701 (= ATCC 33508); its $\mathrm{G}+\mathrm{C}$ content is 50.0 mol\% (as determined by the $\mathrm{CsCl}$ method or $49.9 \mathrm{~mol} \%$ (as determined by the thermal denaturation method).

Nucleotide sequence accession numbers. The nearly complete primary sequences of the $16 \mathrm{~S}$ rRNA genes of $V$. costicola strains which we determined have been deposited in the EMBL data library under the following accession numbers: $V$. costicola NCIMB 701 ${ }^{\mathrm{T}}, \mathrm{X} 95527 ; V$. costicola AV3, X95528; $V$. costicola 6, X95531; $V$. costicola E-367, X95529; V. costicola V-15, X95530; and V. costicola $\mathrm{H}-178, \mathrm{X} 95532$.

We express our appreciation to A. Arnscheidt and A. Krüger for their technical assistance and thank M. T. García for her help during the course of this work. We also thank E. Stackebrandt for the use of unpublished 16S rRNA sequence data for $V$. cholerae.

This study was supported in part by grants from the European Commission (Generic Project Biotechnology of Extremophiles grant BIO-CT93-02734 and T-Project High Resolution Automated Microbial Identification grant BIOT-CT91-0294), from the Ministerio de Educación y Ciencia, Spain (grants PB-92-0670 and PB93-0920), and from the Junta de Andalucia. 


\section{REFERENCES}

1. Adkins, J. P., M. T. Madigan, L. Mandelco, C. R. Woese, and R. S. Tanner. 1993. Arhodomonas aquaeolei gen. nov., sp. nov., an aerobic, halophilic bacterium isolated from a subterranean brine. Int. J. Syst. Bacteriol. 43:514520.

2. Baumann, P., A. L. Furniss, and J. V. Lee. 1984. Genus Vibrio, p. 518-538 In N. R. Krieg and J. G. Holt (ed.), Bergey's manual of systematic bacteriology, vol. 1. The Williams \& Wilkins Co., Baltimore.

3. Brenner, D. J., G. R. Fanning, F. W. Hickman-Brenner, A. G. Steigerwalt, B. R. Davis, and J. J. Farmer III. 1983. DNA relatedness among Vibrionaceae, with emphasis on the Vibrio species associated with human infection, p. 175-184. In H. Leclerc (ed.), Les bacilles à gram négatif d'intéret médical et en santé publique. INSERM, Paris.

4. Dobson, S. J., T. A. McMeekin, and P. D. Franzmann. 1993. Phylogenetic relationships between some members of the genera Deleya, Halomonas, and Halovibrio. Int. J. Syst. Bacteriol. 43:665-673.

5. Dorsch, M., D. Lane, and E. Stackebrandt. 1992. Towards a phylogeny of the genus Vibrio based on 16S rRNA sequences. Int. J. Syst. Bacteriol. 42:58-63.

6. Felsenstein, J. 1985. Confidence limits on phylogenies: an approach using the bootstrap. Evolution 39:783-791.

7. García, M. T., A. Ventosa, F. Ruiz-Berraquero, and M. Kocur. 1987. Taxonomic study and amended description of Vibrio costicola. Int. J. Syst. Bacteriol. 37:251-256.

8. Gardner, G. A. 1980 . Identification and ecology of salt-requiring Vibrio associated with cured meats. Meat Sci. 5:71-81.

9. Gauthier, G., B. Lafay, R. Ruimy, V. Breittmayer, J. L. Nicolas, M. Gauthier, and $R$. Christen. 1995. Small-subunit rRNA sequences and whole DNA relatedness concur for the reassignment of Pasteurella piscicida (Snieszko et al.) Janssen and Surgalla to the genus Photobacterium as Photobacterium damsela subsp. piscicida comb. nov. Int. J. Syst. Bacteriol. 45:139-144.

10. Gutell, R. R., B. Weiser, C. R. Woese, and H. F. Noller. 1985. Comparative anatomy of 16 S-like ribosomal RNA. Prog. Nucleic Acid Res. Mol. Biol. 32:155-216.

11. Gutiérrez, M. C., M. T. García, A. Ventosa, and F. Ruiz-Berraquero. 1989. Relationships among Vibrio costicola strains assessed by DNA-DNA hybridization. FEMS Microbiol. Lett. 61:37-40.

12. Jukes, T. H., and C. R. Cantor. 1969. Evolution of protein molecules, p. 21-132. In H. N. Munro (ed.), Mammalian protein metabolism. Academic Press, Inc., New York.

13. Kersters, K. 1992. The genus Deleya, p. 3189-3197. In A. Balows, H. G. Trüper, M. Dworkin, W. Harder, and K. H. Schleifer (ed.), The prokaryotes, 2nd ed., vol. 2. Springer-Verlag, New York.

14. Kita-Tsukamoto, K., H. Oyaizu, K. Nanba, and U. Simidu. 1993. Phylogenetic relationships of marine bacteria, mainly members of the family Vibrionaceae, determined on the basis of $16 \mathrm{~S}$ rRNA sequences. Int. J. Syst. Bacteriol. 43:8-19.

15. Kushner, D. J. 1978. Life in high salt and solute concentrations: halophilic bacteria, p. 317-368. In D. J. Kushner (ed.), Microbial life in extreme environments. Academic Press, London.

16. Kushner, D. J., and M. Kamekura. 1988. Physiology of halophilic eubacteria, p. 109-138. In F. Rodríguez-Valera (ed.), Halophilic bacteria. CRC Press, Inc., Boca Raton, Fla.

17. Lane, D. J. 1991. 16S/23S sequencing, p. 115-175. In E. Stackebrandt and M. Goodfellow (ed.), Nucleic acid techniques in bacterial systematics. John Wiley \& Sons, Chichester, United Kingdom.
18. Maidak, B. L., N. Larsen, M. J. McCaughey, R. Overbeek, G. J. Olsen, K. Fogel, J. Blandy, and C. R. Woese. 1994. The Ribosomal Database Project. Nucleic Acids Res. 22:3485-3487.

19. Márquez, M. C., A. Ventosa, and F. Ruiz-Berraquero. 1987. A taxonomic study of heterotrophic halophilic and non-halophilic bacteria from a solar saltern. J. Gen. Microbiol. 133:45-56.

20. Mellado, E., E. R. B. Moore, J. J. Nieto, and A. Ventosa. 1995. Phylogenetic inferences and taxonomic consequences of $16 \mathrm{~S}$ ribosomal DNA sequence comparison of Chromohalobacter marismortui, Volcaniella eurihalina and Deleya salina, and reclassification of $V$. eurihalina as Halomonas eurihalina comb. nov. Int. J. Syst. Bacteriol. 45:712-716.

21. Moore, E. R. B., and R. Christen. Personal communication.

22. Olsen, G. J. 1987. The earliest phylogenetic branchings: comparing rRNAbased evolutionary trees inferred with various techniques. Cold Spring Harbor Symp. Quant. Mol. Biol. 52:825-838.

23. Quesada, E., M. J. Valderrama, V. Béjar, A. Ventosa, M. C. Gutiérrez, F Ruiz-Berraquero, and A. Ramos-Cormenzana. 1990. Volcaniella eurihalina gen. nov., sp. nov., a moderately halophilic nonmotile gram-negative rod. Int. J. Syst. Bacteriol, 40:261-267.

24. Quesada, E., A. Ventosa, F. Rodríguez-Valera, L. Megías, and A. RamosCormenzana. 1983. Numerical taxonomy of moderately halophilic Gramnegative bacteria from hypersaline soils. J. Gen. Microbiol. 129:2649-2657.

25. Quesada, E., A. Ventosa, F. Ruiz-Berraquero, and A. Ramos-Cormenzana 1984. Deleya halophila, a new species of moderately halophilic bacteria. Int. J. Syst. Bacteriol. 34:287-292.

26. Rodríguez-Valera, F., A. Ventosa, G. Juez, and J. F. Imhoff. 1985. Variation of environmental features and microbial populations with salt concentrations in a multi-pond saltern. Microb. Ecol. 11:107-115.

27. Ruimy, R., V. Breittmayer, P. Elbaze, B. Lafay, O. Boussemart, M. Gauthier, and R. Christen. 1994. Phylogenetic analysis and assessment of the genera Vibrio, Photobacterium, Aeromonas, and Plesiomonas deduced from smallsubunit rRNA sequences. Int. J. Syst. Bacteriol. 44:416-426.

28. Shewan, J. M., and M. Veron. 1974. Genus Vibrio, p. 340-345. In R. E. Buchanan and N. E. Gibbons (ed.), Bergey's manual of determinative bacteriology, 8th ed. The Williams \& Wilkins Co., Baltimore.

29. Smith, F. B. 1938. An investigation of a taint in rib bones of bacon. The determination of halophilic vibrios (n. spp.). Proc. R. Soc. Queensl. 49:2952 .

30. Valderrama, M. J., E. Quesada, V. Béjar, A. Ventosa, M. C. Gutiérrez, F. Ruiz-Berraquero, and A. Ramos-Cormenzana. 1991. Deleya salina sp. nov., a moderately halophilic gram-negative bacterium. Int. J. Syst. Bacteriol. 41: 377-384.

31. Ventosa, A., M. C. Gutiérrez, M. T. García, and F. Ruiz-Berraquero. 1989. Classification of "Chromobacterium marismortui" in a new genus, Chromohalobacter gen. nov., as Chromohalobacter marismortui comb. nov., nom. rev. Int. J. Syst. Bacteriol. 39:382-386.

32. Ventosa, A., E. Quesada, F. Rodríguez-Valera, F. Ruiz-Berraquero, and A. Ramos-Cormenzana. 1982. Numerical taxonomy of moderately halophilic Gram-negative rods. J. Gen. Microbiol. 128:1959-1968.

33. Vreeland, R. H. 1992. The family Halomonadaceae, p. 3181-3188. In A. Balows, H. G. Trüper, M. Dworkin, W. Harder, and K. H. Schleifer (ed.), The prokaryotes, 2nd ed., vol. 2. Springer-Verlag, New York.

34. Woese, C. R., R. Gutell, R. Gupta, and H. F. Noller. 1983. Detailed analysis of the higher-order structure of 16S-like ribosomal ribonucleic acids. Microbiol. Rev. 47:621-669. 